DOI: $\underline{10.20472 / B M .2019 .7 .2 .007 ~}$

\title{
CORPORATE GOVERNANCE, SHAREHOLDER PROPOSAL, AND CORPORATE PERFORMANCE -EVIDENCE FROM TAIWAN
}

\author{
MEI-HUNG HUANG, SO-DE SHYU, YIH JENG , YIH JENG , SO-DE SHYU
}

\begin{abstract}
:
In this research, through taking Tobin's $q$ and ROE as the performance proxy variables and using panel data model for the empirical research, we mainly studied the relationship between the corporate governance and the corporate performance of the listed companies in Taiwan stock market from year 2010 to 2012 with the shareholders exercising the proposal rights. The results revealed that the shareholding proportion of the institutional investors and the salary of the board members are in the significant negative correlation with the corporate performance of the listed companies at the stock market. The corporate governance index and the corporate performance are in significant negative correlation for the listed companies at the over-the-counter market. No matter if the listed company is at the stock market or at the over-the-counter market, the board size and the corporate performance are in significant negative correlation.
\end{abstract}

\section{Keywords:}

Shareholder Proposal, Corporate Governance, Corporate Performance, Panel Data, Taiwan Stock Market

JEL Classification: G30, G34

\section{Authors:}

MEI-HUNG HUANG, Over Seas Chinese University ; National Sun Yat-sen University, Taiwan, Taiwan, Email: tiffanyhuang428@gmail.com

SO-DE SHYU, Department of Banking and Finance, Takming University of Science and Technology, Taipei, Taiwan, Taiwan, Email: dshyu@takming.edu.tw

YIH JENG , National Sun Yat-Sen University, Taiwan., Taiwan, Email: yihjeng2@gmail.com YIH JENG , National Sun Yat-Sen University, Taiwan., Taiwan, Email: yihjeng2@gmail.com SO-DE SHYU, Department of Banking and Finance, Takming University of Science and Technology, Taipei, Taiwan, Taiwan, Email: dshyu@takming.edu.tw

\section{Citation:}

MEI-HUNG HUANG, SO-DE SHYU, YIH JENG , YIH JENG , SO-DE SHYU (2019). Corporate Governance, Shareholder Proposal, and Corporate Performance -Evidence from Taiwan. International Journal of Business and Management, Vol. VII(2), pp. 94-109., 10.20472/BM.2019.7.2.007 


\section{Introduction}

There happened some serious finance and stock market crisis caused by the issues of accounting fraud, manipulation of profit and loss, inflating earnings and assets, underestimating liabilities and loss, substantial costs improper capitalization, and CPA making financial statement fraud. From year 1998 to 2010, there were over 45 listed companies at the Taiwan stock exchange market having finance crisis. Bebchuk(2005) Through the authorization letters, the managers could select the preferred shareholders to be the board members. Since so, there is no way to supervise self-serving managers to prevent them from acting improper to hurt the rights and the profits of the shareholders. Since no trust to the board members, the activist shareholders intend to impact the company decisions through the active ways, such as shareholder proposals and personal negotiations. Nowadays, shareholder activism has turned to be an important power (Thomas and Cotter, 2007) which gradually increases the influence on the company administration and performance. A common example of shareholder activism is shareholder proposals. Some scholars stated that shareholder proposals would help to maximize the expected company profits. Moreover, shareholder proposal is an effective way to eliminate agency problem, and works well on processing external control, ceasing argument, increasing the positive abnormal returns, and supervising the company administration. (Bebchuk(2005), Gompers et al.(2003), Cǔnat et al. (2012)) However, some scholars pointed out that shareholder proposal would not benefit the maximizing of the expected company profits. Harris and Raviv(2010) thought the shareholders exercising proposal rights might drawback the benefits of other shareholders because having the conflict in interest with other shareholders, or being in short of the information. Looking around the documentation of shareholder proposals, we found that more study targets focused on the companies in the USA. And, the related studies tended to concentrate at the influence of the shareholder votes, the roles of the shareholder proposal for corporate governance, and the possibility of making profit for the shareholders if the cooperate governance getting improved. In such related subjects, there are only few researches taking UK and the European countries as the study target. Most studies of active shareholders and shareholder proposal in Taiwan focused at legal related fields.

In this research, we studied the listed companies selected from Market Observation Post System(MOPS).The listed companies at Taiwan stock market over-the-counter market from year 2010 to 2012 were selected as the samples. Through tracing panel data model analysis, we studied the influence of the shareholder proposals on the ownership structure, supervision mechanism, salary, and corporate governance index to the company performance.

This research is different from other similar studies at two points listed as follows.

(1) Although many scholars studied shareholder proposals and active shareholders, only few empirical researches focused on the cases in Taiwan. In this study, we used the panel data model of pooling of cross-section and time-series data for the empirical analysis.

(2) Most empirical studies either took active shareholders as by-variable with institutional investors for regression analysis, or took active shareholders and corporate governance for variance analysis. In this research, we studied the difference of corporate governance and company performance between the listed companies with and without exercising the Shareholder Proposals. 


\section{Literature Review}

1. Research Hypothesis and Literature Review (1) Ownership Structure and Company Performance Hypothesis I: The shareholding proportion of the management level and the company performance has the correlation

Jensen and Mecking (1976) brought up Convergence-Of-Interest Hypothesis, which the shareholding proportion of the management level getting higher would cause more incentives to enhance the company performance. Jensen and Ruback(1983) brought up Conflict of Interest Hypothesis, which the shareholding proportion of the management level getting higher would make the managers come up with some anti-takeover behaviors for the concern of securing the job positions. Morck et al. (1988) also brought up two hypothesis, which the shareholding proportion of internal shareholders getting higher would make the company performance better, whereas the proportion of inside shareholders reaching to a specific level would increase the insider voting rights to secure the position. This would make the agency problem more seriously, and decrease the company value. From the analysis above, empirical results are shown that the insider shareholding proportion and company performance are in nonlinear relationship.

\section{Hypothesis II: The proportion of the major shareholder and the company performance has the correlation.}

Shleifer and Vishny(1986)and Morck et al.(1988) thought that the shareholding proportion of major shareholders and company performance are in positive correlation. Dispersing minor shareholders cannot gain the profits from the high-cost supervision, while the major shareholders can supervise the managers and enhance the company values. Steiner(1996)had the different point. That the major shareholders have the incentives to supervise the manager to eliminate the agency problem could be probably also because they intend to obtain the decision control rights to be the major shareholders, not only because they want to supervise the managers. From that point, the shareholding proportion of the major shareholders getting higher might enable them to get the higher probability of grabbing the company assets. The shareholding proportion of the major shareholder and the accompany performance are in the negative correlation.

\section{Hypothesis III: The shareholding proportion of institutional investors and the company performance has the correlation.}

Pound (1988) thought that institutional investors would have more professional knowledge and skills. If the managers are supervised by the institutional investors, the supervision cost would be decreased than the one by other shareholders. The institutional investors would make the supervision more efficiently. Agrawal and Mandelker (1990), McConnell and Servaes(1990), Steiner(1996)thought that the company values would get higher when the shareholding proportion of the institutional investors is getting higher. Barnhart and Rosenstein(1998)thought that the shareholding proportion of institutional investor and the company performance are in negative correlation.

(2) Supervision Mechanism and Company Performance Hypothesis IV: The board size and the company performance have the correlation. 
Mayers et al. (1997) stated that the larger board size would benefit the company operation decisions for providing more ideas and suggestions based on the wider technical background and the better education level of the board members.

Chaganti et al. (1985) stated that the board size and the company performance are in positive correlation. Stewardship theory addressed that the board should not serve as a supervision group to the managers but serve as a group of supporters and consultants (Dalton and Daily, 1999). Lipton and Lorsch (1992) stated that large board size would harm the company decisions, and might turn down the supervision function. Therefore, they suggested that the board should be kept for no more than ten members. Cheng (2008) thought that the large board would get the more serious fluctuation at company performance because of the more different opinions from the board. Jensen (1993) and Yermack (1996) revealed that the companies with the small board would have the better performance.

\section{Hypothesis V: The independent board members and the company performance have the correlation.}

Fama (1980), Fama and Jensen (1983) pointed out that external board members would increase the company values by providing the professional knowledge and the supervision mechanism. The research of Millestein and Macavoy (1998) revealed that the companies with the better governance mechanism have the better average operation performance than the ones with no independent board members. Firstenberg and Malkiel (1980) thought that independent board members can bring in the wider ranges of the industry operation experiences. Huson et al. (2001) stated that independent board members would have the independent supervision and professional evaluation skills to enable the companies to make the decisions more efficiently. Duan (1987) stated that the independent board members are thought to be equipped with the power to supervise the high-level managers in the company. Their main responsibility is to increasing the whole company values by instructing the managers to operate the business. If the boards are mainly formed by the independent board members, the managers are supervised and controlled easily. However, in the study of Agrawal and Knoeber (1995), the company performance and the proportion of the independent board members would have the significant negative correlation while the proportion of the independent board members is too high.

\section{Hypothesis IV: The supervisor amount and the company performance have the correlation.}

Shyy and Vijayaraghavan (1996) found that the company performance gets better when there are supervisors. Ho (2003) indicated that the supervisors and the company performance are in the positive correlation. When the amount and the proportion of the supervisors get high, the agency cost gets down and supervision gets more effective. Chen (2002) stated that the proportion of juristic person supervisors and the company operation performance are in the negative correlation but not reaching to the significant standard in statistics.

\section{(3) Salary and Company Performance}

The model established by Holmström (1979) provides the important theoretical foundation of the relationship of the salary offers and company performance. The model presents that the managers, to give the agents the incentives of good efforts, 
would like to evaluate the agents by the company performance while the agents' behaviors cannot be fully observed.

\section{Hypothesis VII: The salary of the managers and the company performance are in correlation.}

The salary of the high-level managers and the company performance are in the significant positive correlation Carpenter and Sanders (2002). Bryan and Hwang (1997) found that the manager's stock share amounts and the salary level are in negative correlation. If the companies offer the salary not fulfilling the managers' expectation, the managers might not be inspired, and would even make the improper decisions to the companies. However, if the companies offer managers the over-high salary compensation but do not supervise their works properly, the maximization of the shareholder's benefits could not be achieved as well.

\section{Hypothesis VIII: The salary of the board members and the company performance has the correlation.}

Different board member salary types have different connections to company performance. Cordeiro et al. (2000) indicated that company performance has the positive correlation with external board member stock offers, but has the negative correlation with the cash compensation. Bryan et al. (2000), Brick et al (2006) found that company performance has the positive correlation with the external board member basic stock compensation, but has no relationship with the cash compensation.

\section{(4) Corporate Governance and Company Operation Performance}

Corporate governance enables the investors and related people to be treated fairly and equally, which ensures the related people trust the company. The company with the good governance could gain the trust in international capital markets and obtain the funds, which keeps the company competitive for long-term.

\section{Hypothesis XI: The corporate governance and the company performance have the correlation.}

Gompers et al. (2003) stated that G-index (governance index) has the significant negative correlation with the company values. Stock (2003) stated that the company with worse corporate governance would generally get the worse performance in finance. Beth (2003) stated that corporate governance and financial performance have the certain correlation.

\section{Methods \\ 1. Variables}

We did the research based on the scopes of the ownership structure, supervision mechanism, salary, corporate governance, and company operation performance. The variables of the ownership structure are the shareholding proportion of major stockholders (SH), the shareholding proportion of management level (TOPFIVE), and the shareholding proportion of institutional investors (INS). The variables of the supervision mechanism are board size (BOARDSIZE), independent board members (IND), and the amount of the supervisors (SN). The variables of salary are manager salary (LNCOMP), and board member salary (DRMP). The variable of corporate governance is governance index (GINDEX). The variables are listed in Table 3-1. The 
data resource of the variables is Taiwan Economic Journal (TEJ).

Table 3-1 Definition of the Variables

\begin{tabular}{|c|c|}
\hline Variable & Definition \\
\hline $\begin{array}{l}\text { Shareholding proportion of the } \\
\text { major shareholders }(\mathrm{SH})\end{array}$ & individuals with the shareholding proportion more than $5 \%$ \\
\hline $\begin{array}{l}\text { Shareholding proportion of the } \\
\text { management level (TOPFIVE) }\end{array}$ & $\begin{array}{l}\text { the top five shareholders with shareholding proportion more than } \\
10 \%\end{array}$ \\
\hline $\begin{array}{l}\text { Shareholding proportion of the } \\
\text { institutional investors(INS) }\end{array}$ & $\begin{array}{l}\text { government institute + local (finance organizations + trust fund + } \\
\text { corporate juridical person) + overseas (finance organizations + } \\
\text { trust fund + corporate juridical person) }\end{array}$ \\
\hline Board size (BOARDSIZE) & the amount of the board members \\
\hline $\begin{array}{l}\text { Independent board member } \\
\text { (IND) }\end{array}$ & $\begin{array}{l}\text { If having independent board members, the virtual variable is set } \\
\text { as } 1 \text {. Otherwise, } 0 \text {. }\end{array}$ \\
\hline Amount of the supervisors $(\mathrm{SN})$ & the number of supervisors \\
\hline Capital expenditure rate(GCE) & $\begin{array}{l}\text { (the later capital expenditure - the previous capital expenditure) / } \\
\text { the previous capital expenditure }\end{array}$ \\
\hline $\begin{array}{l}\text { Proportion of R\&D expenses to } \\
\text { the total assets (RDA) }\end{array}$ & (Research fees * operation net income) / total assets \\
\hline $\begin{array}{l}\text { Proportion of net profit before } \\
\text { interest and tax to the total } \\
\text { assets (ETA) }\end{array}$ & $\begin{array}{l}\text { (net profit before interest and tax }+ \text { depreciation }+ \text { amortization)/ } \\
\text { total assets }\end{array}$ \\
\hline Shareholders' equity(ROE) & net profit after tax / shareholder's equity \\
\hline Tobin's Q & $\begin{array}{l}\text { (common stock capital + special stock capital + total liabilities) / } \\
\text { total assets }\end{array}$ \\
\hline G-INDEX & $\begin{array}{l}\text { the duality of the chairman of the board + board size }+ \text { the } \\
\text { shareholding proportion of the major shareholders }+ \text { the } \\
\text { shareholding proportion of the management level }\end{array}$ \\
\hline $\begin{array}{l}\text { General Manager Salary } \\
\text { (COMP) }\end{array}$ & general manager's salary + bonus \\
\hline Market Book Value (BM) & net value per share / stock price \\
\hline Market Value(MV) & outstanding shares * unadjusted closing price \\
\hline Total Assets (TA) & $\begin{array}{l}\text { current assets + long-term investment + fixed assets + other } \\
\text { assets }\end{array}$ \\
\hline Board Member Salary (DRMP) & traveling expenses + rewards \\
\hline
\end{tabular}

\section{Data Resource and Sample Selection Standard}

The samples for this study are the listed companies at Taiwan stock exchange market and the ones at over-the-counter market. Because financial industry has the different industry structure and has the strict control, the companies in this field were removed from the sample pool. Because the data before year 2010 has lots of missing parts, we selected the data from $01 / 01 / 2010$ to $12 / 31 / 2012$. During this period of time, there were 47 proposals proposed by the shareholders from the listed companies at stock exchange market, and 39 issues proposed by the shareholders from the listed companies at over-the-counter market. Based on the shareholder meeting records of these companies, for the listed companies in the stock market, after all, there were two issues with the proposal drawback, 17 issues with no proposal, and 11 issues not listed in the meeting discussion for not fulfilling the board standard. There are 17 effective 
proposals from the listed companies at the stock market. For the listed companies at over-the-counter market, after all, there were one issue with missing data, 26 issues with no proposal, and four issues not listed in the meeting discussion for not fulfilling the board standard. There were only eight effective proposals for the listed companies at the over-the-counter market. For all the listed companies, there were 25 effective proposals proposed by the shareholders in 20 companies. Therefore, there are 20 companies in the sample pool. We used "similar scale", "same industry", and "similar business" as the matching principles in our study Beaver (1966). With the ratio of 1:1, we selected the 20 companies as the samples in the comparison group.

\section{Empirical Model}

(1) Company Performance Model

For revealing the influence of the ownership structure, supervision mechanism, and salary to the company operation performance, we took Tobin's $q$ and ROE as the proxy variables for company performance. The model is established as follows.

$$
\begin{aligned}
& \text { Tobin's } q_{i, t}=\beta_{0}+\beta_{1} \text { SH }_{i, t}+\beta_{2} \text { TOPFIVE }_{i, t}+\beta_{3} \text { INS }_{i, t}+\beta_{4} \text { BOARDSIZE }_{i, t}+\beta_{5} \text { IND }_{i, t}+\beta_{6} \text { SN }_{i, t} \\
& +\beta_{7} \text { LNCOMP }_{i, t}+\beta_{8} \text { LNDRMP }_{i, t}+\beta_{9} \text { Gindex }_{, i t}+\beta_{10} \text { BM }_{i t}+\beta_{11} \text { LNMV }_{i, t}+\beta_{12} \text { LNTA }_{i, t} \\
& +\beta_{13} \mathrm{GCE}_{\mathrm{i}, \mathrm{t}}+\beta_{14} \mathrm{RDA}_{\mathrm{i}, \mathrm{t}}+\beta_{15} \mathrm{ETA}_{\mathrm{i}, \mathrm{t}}+\varepsilon_{\mathrm{i}, \mathrm{t}}
\end{aligned}
$$

$$
\begin{aligned}
& \text { ROE }_{i, t}=\beta_{0}+\beta_{1} \text { SH }_{i, t}+\beta_{2} \text { TOPFIVE }_{i, t}+\beta_{3} \text { INS }_{i, t}+\beta_{4} \text { BOARDSIZE }_{i, t}+\beta_{5} \text { IND }_{i, t}+\beta_{6} \text { SN }_{i, t} \\
& +\beta_{7} \text { LNCOMP }_{i, t}+\beta_{8} \text { LNDRMP }_{i, t}+\beta_{9} \text { Gindex }_{, i t}+\beta_{10} \text { BM }_{i t}+\beta_{11} \text { LNMV }_{i, t}+\beta_{12} \text { LNTA }_{i, t} \\
& +\beta_{13} \mathrm{GCE}_{\mathrm{i}, \mathrm{t}}+\beta_{14} \mathrm{RDA}_{\mathrm{i}, \mathrm{t}}+\beta_{15} \mathrm{ETA}_{\mathrm{i}, \mathrm{t}}+\varepsilon_{\mathrm{i}, \mathrm{t}}
\end{aligned}
$$

$i$ : represents the ith company; $t$ represents sample data from $t$ year

(2) Panel Data Model

We used Panel Data Model for the analysis in this research. Based on the different ways of estimates, the models could be categorized as Fixed-Effect Model known as Dummy Variable Model which uses fixed intercept to represent the different structure, and Random-Effect Model known as Error Component Model which uses random intercept to represent the different structure of every cross section. F test, LM (largrange multiplier) test, and Hausman test could be used to find out the most suitable model for the latitude data.

\section{Results}

\section{Pearson Correlation Coefficient}

In Table 4-1 the correlation coefficients of two variables are all smaller than 0.85 , which means they are not collinear.

\section{Table 4-1 Pearson Correlation Coefficient}

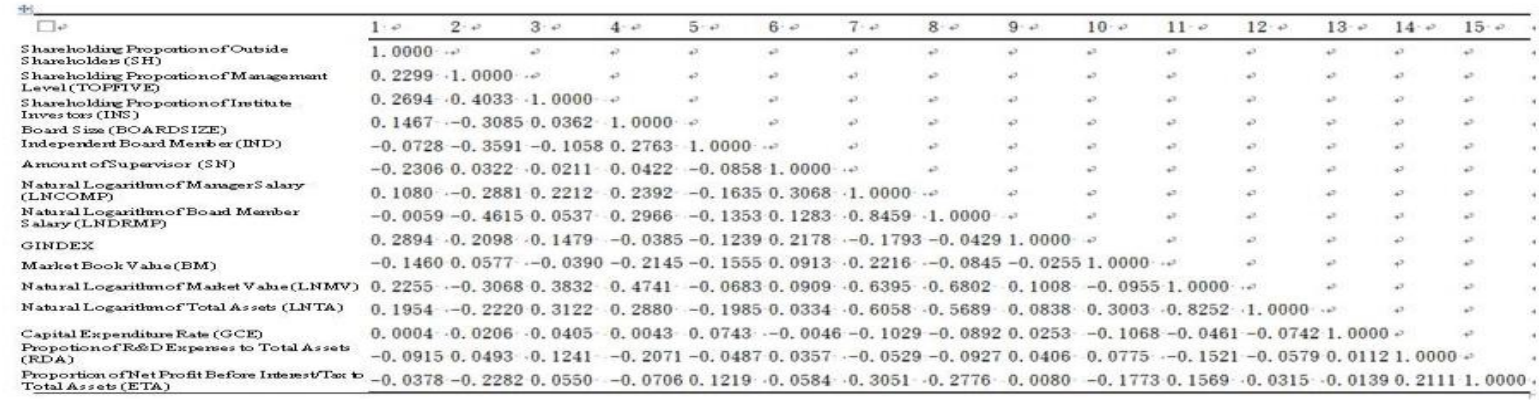




\section{Optimal Model Test}

Full sample optimal model test can be categorized as the companies with the shareholders exercising the proposal rights and the ones without the shareholders exercising the proposal rights. To this model, we came up four regression equations with two performance indicators and two sample companies. The optimal model test for the listed companies categorizes the full samples into the ones with the shareholders exercising the proposal rights and the ones without the shareholders exercising the proposal rights. To this model, we generated eight regression equations with two performance indicators and two sample companies. F-test, LM-test and Hausman-test were applied to these regression equations to find out the optimal empirical model. At the full sample test ROE model with the shareholder exercising proposal rights, the random effect works better for the Hausman-test does not reject null hypothesis. At all others, the fixed effect works better for Hausman-test reject null hypothesis. The results are shown at Table 4-2.

Table 4-2 the Optimal Model Test of the Full Samples and Listed Companies

\begin{tabular}{|c|c|c|c|c|}
\hline $\begin{array}{l}\text { Performance } \\
\text { Indicator }\end{array}$ & \multicolumn{2}{|l|}{ Tobin's q } & \multicolumn{2}{|c|}{ ROE } \\
\hline $\begin{array}{l}\text { Exercising } \\
\text { Shareholder } \\
\text { Proposals }\end{array}$ & Yes & No & Yes & No \\
\hline \multicolumn{5}{|c|}{ Panel A Full Sample Optimal Model Test } \\
\hline F-test & $2048.95^{\star * \star}$ & $1628.45^{\star \star \star}$ & $419.09^{* \star *}$ & $497.18^{\star * \star}$ \\
\hline LM-test & $1.1 \mathrm{e}+06^{\star \star \star}$ & $8.9 e+05$ & $3.4 \mathrm{e}+05^{\star \star \star}$ & $4.2 \mathrm{e}+05^{\star \star *}$ \\
\hline \multirow{2}{*}{$\begin{array}{l}\text { Hausman-test } \\
\text { optimal model }\end{array}$} & $60.28^{* * *}$ & $120.68^{* * *}$ & 13.46 & $40.04^{* * *}$ \\
\hline & Fixed effects & Fixed effects & Random effects & Fixed effects \\
\hline \multicolumn{5}{|c|}{ Panel B Listed Company at Stock Exchange Market Optimal Model Test } \\
\hline F-test & $739.26^{\star \star \star}$ & $1633.27^{\star \star \star}$ & $370.60^{\star \star *}$ & $207.29^{\star \star \star}$ \\
\hline LM-test & $1.0 \mathrm{e}+05^{\star \star *}$ & $8.0 \mathrm{e}+05^{\star * *}$ & $25552.40^{\star \star \star}$ & $28886.64^{* * *}$ \\
\hline Hausman-test & $3262.79^{* * *}$ & $1236.11^{\star \star \star}$ & $4140.24^{\star \star *}$ & $1309.46^{\star \star \star}$ \\
\hline optimal model & Fixed effects & Fixed effects & Fixed effects & Fixed effects \\
\hline \multicolumn{5}{|c|}{ Panel C Listed Company at Over-the-Counter Market Optimal Model Test } \\
\hline F-test & $742.31^{* \star \star}$ & $728.98^{\star \star \star}$ & $188.30^{\star \star \star}$ & $141.39^{* * *}$ \\
\hline LM-test & $4036.77^{\star \star \star}$ & $3002.96^{\star \star \star}$ & $1404.19^{\star \star \star}$ & 1.95 \\
\hline Hausman-test & $5522.99^{* * *}$ & $4918.00^{\star \star *}$ & $1203.34^{\star \star *}$ & $851.34^{\star \star \star}$ \\
\hline optimal model & Fixed effects & Fixed effects & Fixed effects & Fixed effects \\
\hline
\end{tabular}

Note : ${ }^{*}$ represents reaching the significance at 0.10 significant level. ${ }^{* *}$ represents reaching the significance at 0.05 significant level;

${ }^{* * *}$ represents reaching the significance at 0.01 significant level

\section{Panel Data Model Regression Empirical Results}

(1) Full Sample Regression Empirical Results

From Table 4-3, at the companies with the shareholder exercising proposal rights, the shareholding proportion of large outside shareholders and the board member salary have the positive correlation with Tobin's q. At the listed companies with no shareholders exercising proposal rights, the shareholding proportion of the management level and the board member salary have significant negative correlation with Tobin's $q$. That the shareholding proportion of the management level and the corporate performance are in significant negative correlation means supporting the "Conflict of Interest Hypothesis" (Jensen and Ruback (1983)) in which the managers, for the concern of their job security, would have the 
anti-takeover behaviors when they have the higher shareholding proportion. That the board member salary and the operation performance are in the significant negative correlation means the board members are not functioning well at supervision. At the listed companies with no shareholder exercising proposal rights, the shareholding proportion of the institutional investors, the board size, the amount of the supervisors, the salary of the managers, and the company governance index have the significant positive correlation with Tobin's q. That the shareholding proportion of the institutional investors and the company performance has the significant positive correlation means the support of Efficient Monitoring Hypothesis Pound (1998). Because the institutional investors have the professional knowledge, they make the supervision more efficiently. The board size and the company performance have the significant positive correlation, which supports the study result of Mayers et al. (1997). The more board members, the more professional knowledge and suggestions in various fields could be provided by them to support the company decision-making procedure. The numbers of supervisors and the company performance have significant positive correlation, which supports the findings of Shyy and Vijayaraghavan (1996). The manager's salary and the corporate governance index have the significant positive correlation with the company performance, which the high-salary stimulates the managers to work hard to manage the companies so that the shareholders have no reason to exercise the proposal rights. To the listed companies with no shareholder exercising proposal rights, the shareholding proportion of the large shareholders and Tobin's q have no significant correlation, which supports the research results of McConnell and Servaes (1990)

At the listed companies with the shareholder exercising proposal rights, the shareholding proportion of the outside stockholders, the shareholding proportion of the institutional investors, the board size, the independent board members, the salary of the board members have the significant negative correlation with ROE, which supports the "Interest Conflict Hypothesis" brought up by Jensen and Ruback (1983). The board size and the company performance have the significant negative correlation, which supports Cheng (2008)'s study. At the listed companies with the shareholder exercising proposal rights, the number of supervisors, the salary of the managers, and the corporate governance index have the significant positive correlation with ROE. At the listed companies with no shareholder exercising proposal rights, the shareholding proportion of the outside shareholders, the shareholding proportion of the management level, the amount of the supervisors, and the independent board members have the significant positive correlation with ROE.

At the listed companies with no shareholder exercising proposal, the shareholding proportion of the institutional investors, the manager's salary, and the company governance index have the significant negative correlation with ROE. The shareholding proportion of the management level and the company performance have the significant positive correlation, which supports Interest Convergence Hypothesis brought by Jensen and Meckling (1976).When the shareholding proportion of the management level is high, the managers would get loss if the company's profits get down. Therefore, the shareholding proportion of the management level is the incentive for the managers to dedicate their efforts to the company. The amount of the supervisors and the 
company performance are in the significant positive correlation, which supports the study of Yeh et al. (2002). When getting more supervisors, the company gets the better supervision and decreases the agency cost to enhance the company performance. Independent board members and the operation performance have the significant positive correlation, which supports Duan's study (1987). Independent board members are taken as the force to supervise the high-level managers in the company. Their major responsibility is to enhance the company profits by instructing the managers at the business operation. If the board is mainly formed by the independent board members, the managers would be supervised more efficiently.

Table 4-3 Full Sample Regression Empirical Results

\begin{tabular}{|c|c|c|c|c|}
\hline \multirow{2}{*}{$\begin{array}{c}\text { Performance Indicator } \\
\text { Exercising Shareholder Rights }\end{array}$} & \multicolumn{2}{|c|}{ Tobin's q } & \multicolumn{2}{|c|}{ ROE } \\
\hline & Yes & No & Yes & No \\
\hline Intercept & $\begin{array}{c}4.2482^{\star \star \star} \\
(0.1223)\end{array}$ & $\begin{array}{l}0.1499^{\star *} \\
(0.0697)\end{array}$ & $\begin{array}{c}-0.4166^{\star * *} \\
(0.0483)\end{array}$ & $\begin{array}{c}0.1442^{\star * *} \\
(0.0310)\end{array}$ \\
\hline Shareholding proportion of the & $0.0029^{\star * \star}$ & -0.0001 & $-0.0006^{* * *}$ & $0.0004^{* * *}$ \\
\hline Outside Shareholders (SH) & $(0.0001)$ & $(0.0001)$ & $(0.0001)$ & $(0.0000)$ \\
\hline Shareholding Proportion of & 0.0000 & $-0.0021^{\star \star \star}$ & $0.0008^{* \star *}$ & $0.0004^{\star \star *}$ \\
\hline Management Level (TOPFIVE) & $(0.0002)$ & $(0.0002)$ & $(0.0001)$ & $(0.0001)$ \\
\hline Shareholding Proportion of & $-0.0029^{* \star *}$ & $0.0016^{\star * *}$ & $-0.0002^{* *}$ & $-0.0002^{* \star *}$ \\
\hline Institutional Investors (INS) & $(0.0002)$ & $(0.0001)$ & $(0.0001)$ & $(0.0000)$ \\
\hline Board Size & $-0.0171^{\star * *}$ & $0.0200^{* \star *}$ & $-0.0029^{* * *}$ & 0.0004 \\
\hline (BOARDSIZE) & $(0.0015)$ & $(0.0009)$ & $(0.0006)$ & $(0.0004)$ \\
\hline $\begin{array}{c}\text { Independent Board Member } \\
\text { (IND) }\end{array}$ & $\begin{array}{l}-0.0762^{\star * *} \\
(0.0081)\end{array}$ & (dropped) & $\begin{array}{l}-0.0199^{* * *} \\
(0.0035)\end{array}$ & (dropped) \\
\hline $\begin{array}{c}\text { Number of Supervisor } \\
(\mathrm{SN})\end{array}$ & $\begin{array}{l}-0.0037 \\
(0.0066)\end{array}$ & $\begin{array}{l}0.0129^{* * *} \\
(0.0009)\end{array}$ & $\begin{array}{c}0.0134^{* \star *} \\
(0.0029)\end{array}$ & $\begin{array}{l}0.0014^{* * *} \\
(0.0004)\end{array}$ \\
\hline $\begin{array}{l}\text { Manager Salary } \\
\text { (LNCOMP) }\end{array}$ & $\begin{array}{l}-0.0906^{* * *} \\
(0.0032)\end{array}$ & $\begin{array}{l}0.0157^{* * *} \\
(0.0042)\end{array}$ & $\begin{array}{l}0.0255^{* * *} \\
(0.0014)\end{array}$ & $\begin{array}{l}-0.0072^{* * *} \\
(0.0019)\end{array}$ \\
\hline $\begin{array}{l}\text { Board Member Salary } \\
\text { (LNDRMP) }\end{array}$ & $\begin{array}{l}0.0053^{*} \\
(0.0032)\end{array}$ & $\begin{array}{l}-0.0064^{* \star *} \\
(0.0012)\end{array}$ & $\begin{array}{l}-0.0114^{* * *} \\
(0.0014)\end{array}$ & $\begin{array}{l}0.0052^{* * *} \\
(0.0005)\end{array}$ \\
\hline GINDEX & $\begin{array}{l}-0.0506^{* * *} \\
(0.0028)\end{array}$ & $\begin{array}{l}0.0367^{* \star \star} \\
(0.0017)\end{array}$ & $\begin{array}{l}0.0145^{* * *} \\
(0.0012)\end{array}$ & $\begin{array}{l}-0.0048^{* * *} \\
(0.0008)\end{array}$ \\
\hline $\begin{array}{l}\text { Market Book Value } \\
\text { (BM) }\end{array}$ & $\begin{array}{l}-0.0741^{* \star *} \\
(0.0043)\end{array}$ & $\begin{array}{c}-0.0333^{\star \star \star} \\
(0.0026)\end{array}$ & $\begin{array}{c}-0.0127^{* * *} \\
(0.0019)\end{array}$ & $\begin{array}{l}0.0003 \\
(0.0012)\end{array}$ \\
\hline $\begin{array}{l}\text { Market Value } \\
\text { (LNMV) }\end{array}$ & $\begin{array}{l}-0.0601^{* * *} \\
(0.0037)\end{array}$ & $\begin{array}{l}-0.0209^{* * *} \\
(0.0026)\end{array}$ & $\begin{array}{l}-0.0210^{* * *} \\
(0.0016)\end{array}$ & $\begin{array}{l}0.0090^{* * *} \\
(0.0012)\end{array}$ \\
\hline Total Assets & $-0.1043^{\star * *}$ & $0.0265^{\star * *}$ & $0.0224^{* * *}$ & $-0.0121^{* * *}$ \\
\hline Capital Expenditure Rate & $0.0000^{\star * *}$ & $0.0001^{* * *}$ & $0.0000^{* * *}$ & $0.0000^{* * *}$ \\
\hline Proportion of R\&D Expense to Total & $0.0160^{\star \star \star}$ & 0.0008 & $-0.0139^{* * *}$ & $-0.0056^{* * *}$ \\
\hline Assets (RDA) & $(0.0019)$ & $(0.0005)$ & $(0.0008)$ & $(0.0002)$ \\
\hline Proportion of Net Profit before & $-4.9449^{* * *}$ & $-0.9087^{\star \star \star}$ & $12.8153^{\star \star \star}$ & $10.7949^{\star \star \star}$ \\
\hline Interest/Tax to Total Assets (ETA) & $(0.1647)$ & $(0.0937)$ & $(0.0720)$ & $(0.0417)$ \\
\hline $\mathrm{R}^{2}$ & 0.3521 & 0.1400 & 0.7668 & 0.8634 \\
\hline
\end{tabular}

(2) The Regression Empirical Results of the Listed Companies

Table4-4 shows the regression empirical results of the listed companies. At the listed companies with the shareholder exercising the proposal rights, the shareholding proportion of the outside major shareholders and the supervisor amount are in significant positive correlation with Tobin's q, but in the significant negative correlation with ROE. At the listed companies with the shareholder exercising the proposal rights, the shareholding proportion of the management level and the manager's salary are in the significant negative correlation with Tobin's q, but in the significant positive correlation with ROE.

At the listed companies with the shareholder exercising the proposal rights, the 
shareholding proportion of the institutional investors, board scale, and the position of independent board members, board member salary, and corporate governance index have the significant negative correlation with Tobin's $q$ and ROE. The shareholding proportion of the institutional investors and the corporate performance are in the significant negative correlation, which supports Conflict of Interest Hypothesis brought up by Pound (1998). The board size and the company performance are in the significant negative correlation, which supports the studies of Cheng (2008), Jensen (1993) and Yermack (1996). The position of independent board member and the operation performance are in significant negative correlation, which supports the researches of Cordeiro et al. (2000), and Agrawal and Knoeber (1995). The corporate governance index and the company performance are in the significant negative correlation, which supports the findings of Gompers et al. (2003), and Bebchuk et al. (2008)

At the listed companies with no shareholder exercising the proposal rights, the shareholding proportion of institutional investors, the board size, the number of supervisor, and the corporate governance index have the significant positive correlation with Tobin's q, but have the significant negative correlation with ROE. At the listed companies with no shareholder exercising the proposal rights, the shareholding proportion of the outside major shareholders, manager's salary, and board member's salary are in significant negative correlation with Tobin's q, in significant positive correlation with ROE. At the listed companies with no shareholder exercising the proposal rights, the shareholding proportion of the management level is in significant negative correlation with Tobin's $q$ and ROE, which supports Conflict of Interest Hypothesis by Jensen and Ruback (1983).

At the listed companies with shareholders exercising the proposal rights, the shareholding proportion of the outside major shareholders, board member's salary and corporate governance index have the significant negative correlation with performance proxy variable, ROE. At the listed companies with no shareholders exercising the proposal rights, the shareholding proportion of the outside major shareholders, board member's salary and corporate governance index have significant positive correlation with company performance. At the listed companies with shareholders exercising the proposal rights, the shareholding proportion of management level and the company performance are in significant positive correlation; whereas the ones with no shareholders exercising the proposal rights, the shareholding proportion of management level and the company performance are in significant negative correlation.

Based on the analysis above, we could infer the five reasons of the shareholders exercising proposal rights.

1. The institutional investors think the managers holding the higher proportion of the stocks would get the more votes, work less for getting more job security, and even come up with the anti-takeover behavior. Eventually, the performance becomes bad.

2. That the board size getting large means that the board would have more board members with the professional knowledge. At this situation, the board members might have more arguments for having more different opinions. The board members might form the factions. This would make the board hard to generate the optimal decisions for the company.

3. The board member's salary cannot make the board members to do the best at supervision. The board member's salary cannot be the incentives for the board 
members to supervise the managers well. This could be because the independent board members are elected through the authorization letters by the managers who bond to the independent board members very well. Or, the board members have other career goals so that the salary could not be the incentives for the board members to serve well.

4. For gaining the profits for their own, the large shareholders would sacrifice the rights of the small shareholders

5. The bad corporate governance index means the bad company performance which harms the rights and the fortune of the shareholders.

Table 4-4 the Regression Empirical Results of the Listed Companies

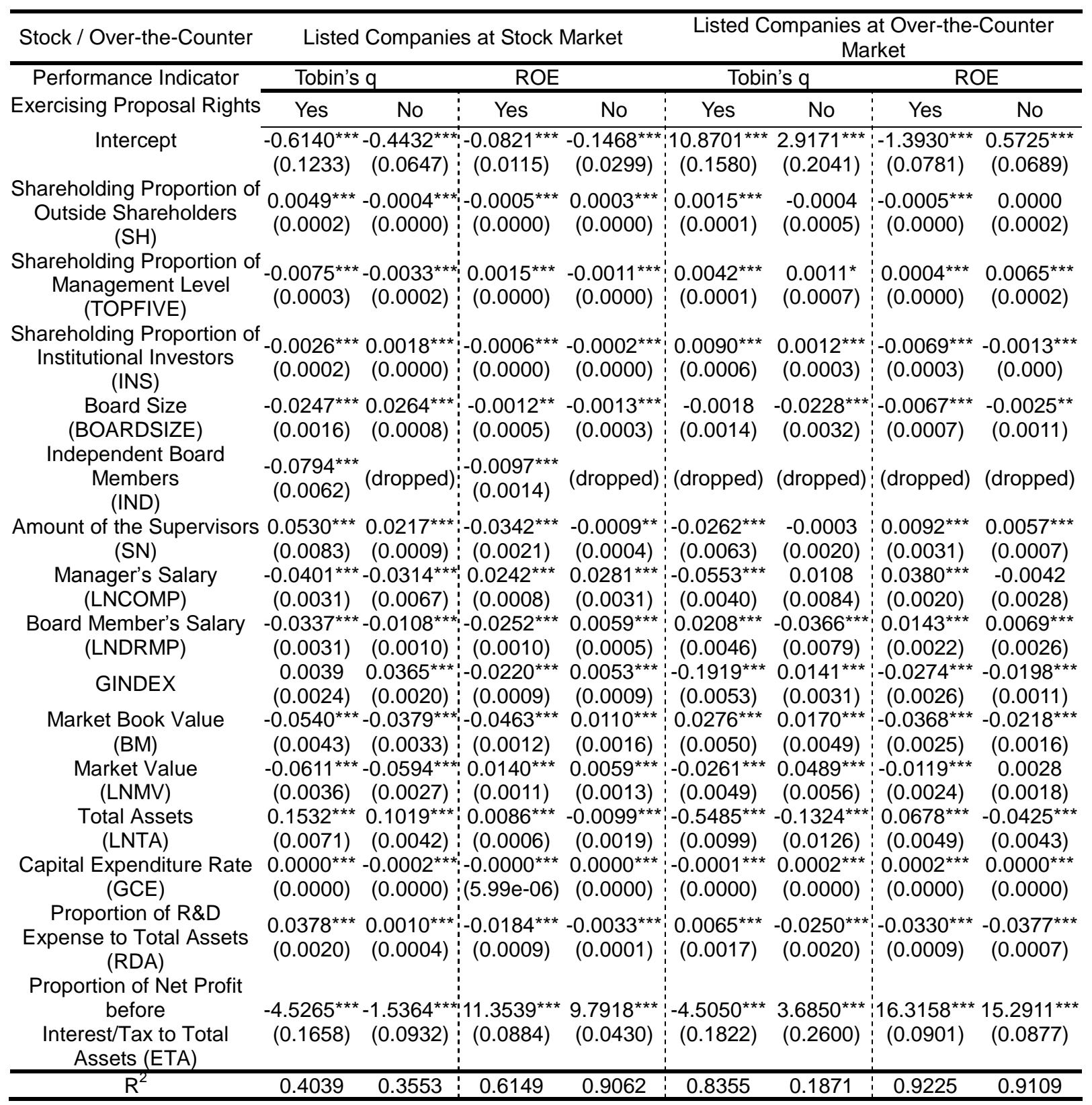


(2) The Listed Companies at the Over-the-Counter Market

At the listed companies with shareholders exercising the proposal rights, the shareholding proportion of major outside shareholders, the shareholding proportion of the management level, the shareholding proportion of the institutional investors, and the board member's salary are in the significant positive correlation with company performance indicator, Tobin's q. At the listed companies with shareholders exercising the proposal rights, the amount of the supervisors, board member's salary, and the corporate governance index have the significant negative correlation with the company performance indicator, Tobin's q. At the listed companies with no shareholders exercising the proposal rights, the shareholding proportion of the management level, the shareholding proportion of the institutional investors, and the corporate governance index have the significant positive correlation with Tobin's q. At the listed companies with no shareholders exercising the proposal rights, the board size, and the manager's salary are in the significant negative correlation with Tobin's q.

At the listed companies with shareholders exercising the proposal rights, the shareholding proportion of the management level, the amount of the supervisors, manager's salary, and the board member's salary are in the significant positive correlation with the company performance indicator, ROE. At the listed companies with shareholders exercising the proposal rights, the shareholding proportion of the outside major shareholders, the shareholding proportion of the institutional investors, the board size are and the corporate governance index are in the significant negative correlation with the company performance indicator, ROE. At the listed companies with no shareholders exercising the proposal rights, the shareholding proportion of the management level, the amount of the supervisors, and the board member's salary are in the significant positive correlation with ROE. At the listed companies with no shareholders exercising the proposal rights, the shareholding proportion of the institutional investors, the board size, and the corporate governance index are in the significant negative correlation with ROE.

From the analysis, at the listed companies with the shareholders exercising proposal rights at the over-the-counter market, the board member's salary and company performance (Tobin's q) are in significant positive correlation. However, at the listed companies with no shareholders exercising the proposal rights, the board member's salary and Tobin's q are in significant negative correlation. At the listed companies with shareholders exercising the proposal rights, the corporate governance index and the company performance are in the significant negative correlation. At the listed companies with no shareholders exercising the proposal rights, the corporate governance index and the company performance are in the significant positive correlation. Therefore, we could get the main reasons that the shareholders in the listed companies at the over-the-counter market exercise proposal rights as follows.

1. The independent board members would think they need to work on what they are supposed to work since they get the finance compensation. And, the managers of listed companies at the over-the-counter market and the major shareholders have the same goals at the business. Therefore, there is no issue on the authorization of the power of attorney.

2. When the corporate governance index gets worse, the company performance gets worse. For protecting the rights and the benefits, the shareholders exercise the proposal rights. 


\section{Conclusion}

1. From the listed companies, we studied the influence of the equity structure, supervision mechanism, salary, and the corporate governance index to the corporate performance. (Variables have the same influence to two performance variables, ROE and Tobin's q)

(1) Equity Structure

The shareholding proportion of the institutional investors and the performance of the listed companies at the stock market are in the significant negative correlation, which supports Conflict of Interest Hypothesis. The investors might sacrifice the profits of other small shareholders for gaining their own profits. The shareholding proportion of the management level and the performance of the listed company at the over-the-counter market are in the significant positive correlation, which means that the managers work hard on decision-making for they consider their profits decreased while the company performance getting bad. Moreover, if the companies get IPO, these managers would get more benefits.

(2) Supervision Mechanism

The board size of the listed companies either at the over-the-counter market or the stock market has the significant positive correlation with the corporate performance. This is probably because the larger board would cause the larger fluctuation at company performance, which makes the board members having more different opinions. In the long-term, this harms the company values. Independent board members and the listed company performance are in significant negative correlation.

(3) Salary

Board member salary and the company performance of the listed companies have the significant negative correlation. This is probably because the board members strongly bond to the managers and cannot supervise the managers well. The board member salary and the performance of the listed companies are in significant positive correlation.

(4) Corporate Governance Index

The corporate governance index and the performance are in significant negative correlation in the listed companies at over-the-counter market. Because the companies are still not qualified for IPO, the corporate governance index is expected to be poor.

2. The reasons and the features of the listed companies with the shareholders exercising the proposal rights were studied.

The stockholders of the listed companies would exercise the proposal rights because the company performance gets worse when the corporate governance index is low. The shareholders exercise the proposal rights to protect their rights. The institutional investors and the large outside shareholders would sacrifice the small shareholder's' rights to protect their own profits. The board probably could not make the best decisions because the board has lots members or the members are generally in selfish departmentalism. The salary of the board members cannot be the incentives of working hard at supervision. This is probably because the board members do not care about the salary and strongly bond to the managers, which is not good for the company performance. 


\section{Reference}

1. Barnhart, S. W. \& S. Rosenstein (1998). Board Composition, Managerial Ownership and Firm Performance: An Empirical Analysis. The financial review, 33, 1-16. https://doi.org/10.1111/j.1540-6288.1998.tb01393.x

2. Bebchuk, L.A. \& A. Cohen (2005). The Costs of Entrenched Boards', Journal of Financial Economics, 78, 409-33. https://doi.org/10.1016/j.jfineco.2004.12.006

3. Brick, I. E., Palmon, O., \& Wald, J. K. (2006). CEO compensation, director compensation, and firm performance: Evidence of cronyism? Journal of Corporate Finance, 12 (3), 403-423. https://doi.org/10.1016/j.jcorpfin.2005.08.005

4. Bryan, S. \& L. Hwang (1997). The Economic Determinants of the CEO Compensation-Performance Sensitivity, Working Paper, Baruch College, CUNY.

5. Bryan, S., Hwang, L., Klein, A., \& Lilien, S. (2000). Compensation of outside directors: An empirical analysis of economic determinants. Working Paper, Social Science Research Network. https://doi.org/10.2139/ssrn.244540

6. Carpenter, M. A., \& W. M. Sanders. (2002). Top management team compensation: the miss link between CEO pay and firm performance? Strategic Management Journal, 23(4), 367-375. https://doi.org/10.1002/smj.228

7. Chen A., L. Kao., M.Tsao \& C.Wu. (2007). Building a Corporate Governance Index from the Perspectives of Ownership and Leadership for Firms in Taiwan, Journal Compilation, 15(2), 251-261. https://doi.org/10.1111/j.1467-8683.2007.00572.x

8. Cheng, S. (2008). Board size and the variability of corporate performance, Journal of Financial Economics, 87, 157-176. https://doi.org/10.1016/j.jfineco.2006.10.006

9. Chung \& Pruitt. (1994), A simple approximation of Tobin's Q. Financial management, 23, 70-74. https://doi.org/10.2307/3665623

10. Fama, E. F., \& Jensen, M. C. (1983). Agency problems and residual claims. Journal of Law and Economics. 26 (2): 327-349. https://doi.org/10.1086/467038

11. Fama, E. F., (1980), Agency Problems and the Theory of the Firm, Journal of Political Economics, Vol. 88, pp. 288-307. https://doi.org/10.1086/260866

12. Harris, m., \& Raviv, a. (2010). Control of corporate decisions: Shareholders vs. management. Review of Financial Studies. 23. 4115-4147. https://doi.org/10.1093/rfs/hhq081

13. Huson, M.R., Parrino, R., \& Starks, L.T. (2001). Internal Monitoring Mechanisms and CEO Turnover. A Long -Term Perspective. Journal of Finance. (56). 2265-2297. https://doi.org/10.1111/0022-1082.00405

14. Firstenberg, P.B., \& Malkiel, B.G. (1980). Why corporate boards need independent directors? Management Review. (4). 26-38

15. Jensen, M. C., \& W. H. Meckling. (1976). Theory of the firm: Managerial behavior, agency costs and ownership structure. Journal of Financial Economics, 3, 305-360. https://doi.org/10.1016/0304-405X(76)90026-X

16. Jensen, Michael C., \& Richard S. Ruback. (1983). The Market for Corporate Control : The Scientific Evidence, Journal of Financial Economics, 11, 5-50. https://doi.org/10.1016/0304-405X(83)90004-1

17. Jensen. M. C. (1993). The Modern Industrial Revolution, Exit, and the Failure of Internal Control Systems. The Journal of Finance. 48(3). 831-880. https://doi.org/10.1111/j.1540-6261.1993.tb04022.x

18. Lipton, M. \& J. Lorsch. (1992). A Modest Proposal Improved Corporate Governance. Business Lawyer. 48. 59-77.

19. Mayers, D., A. Shivdasani, \& C. W. Smith. (1997). Board Composition and 
Corporate Control: Evidence from the Insurance Industry, Journal of Business. 70. 33-62. https://doi.org/10.1086/209707

20. McConnell, J. J. \& H. Servaes. (1990) Additional Evidence on Equity Ownership and Corporate Value. Journal of Financial Economics. 27. 595-612. https://doi.org/10.1016/0304-405X(90)90069-C

21. Millestein, I.M., \& Macavoy, P.W. (1998). The active board of directors and performance of the large publicly traded corporation, Columbia Law Journal, (98). 1283-1321. https://doi.org/10.2307/1123383

22. Morck, R., A. Shleifer, \&. Vishny. (1988). Management ownership and market valuation: An empirical analysis. Journal of Financial and Economics 20(1), 293-315. https://doi.org/10.1016/0304-405X(88)90048-7

23. Pound, J. (1988), Proxy Contests and the Efficiency of Shareholder Oversight. Journal of Financial Economics, 20, 237-265. https://doi.org/10.1016/0304-405X(88)90046-3

24. Shleifer, A. \& R. Vishny. 1997, A survey of Corporate Governance. Journal of finance, 52, 737-783. https://doi.org/10.1111/j.1540-6261.1997.tb04820.x

25. Shyy, G., \& Vijayravan V. (1996), Is a supervisory board valuable? The French evidence, Manuscript, National Central University, Taiwan

26. Steiner, T. L. (1996). A reexamination of the relationships between ownership structure, firm diversification, and Tobin's Q. Quarterly Journal of Business and Economics, 35(4), 39-48.

27. Thomas, R.S., \& Cotter, J.F. (2007). Shareholder proposals in the new millennium: shareholder support, board response, and market reaction. Journal of Corporate Finance 13, 368-391. https://doi.org/10.1016/j.jcorpfin.2007.02.002

28. Yermack, D. (1996). Higher Market Valuation of Companies with a Small Board of Directors. Journal of Financial Economics, 40, 185-211. https://doi.org/10.1016/0304-405X(95)00844-5 